\title{
The Wage Bills of COVID-19
}

\section{YiLi Chien, Research Officer and Economist}

Julie Bennett, Research Associate

T:

o prevent the spread of COVID-19, many states have issued stay-at-home orders, resulting in the full or partial closure of many non-essential businesses, a significant number of layoffs, and therefore a large amount of lost wages. Industries highly affected by the economic shutdown vary substantially in both how much output they produce and their degree of labor intensity - that is, how much labor they require to produce a certain level of output-suggesting that lost wages could be quite heterogeneous across industries. This short article provides rough estimates on the size of the wage loss associated with industries highly impacted by the COVID-19 pandemic.

The largest potential wage loss comes from the health care and social assistance industry.

Industries highly affected by the economic shutdown include, but are not limited to, construction; transportation and warehousing; retail trade (excluding food and beverage stores); administrative and waste management services; educational services (private); health care and social assistance (excluding hospitals); entertainment and recreation; and accommodation and food services. ${ }^{1}$ The table reports each of these industry's labor intensity and output for the second quarter of 2019.

Industrial labor intensity, as reported in the second column of the table, is measured by the worker compensationto-output ratio, using data from 2018. The average labor intensity across all private industries is 0.5 ; the industries heavily impacted by COVID-19, therefore, all have a higherthan-average labor intensity, ranging from 0.54 to 0.8 . In particular, the labor intensity levels of social assistance (e.g., child care facilities) and nursing home facilitiessectors within the health care and social assistance industry-exceed 0.9. The third column of the table reports the GDP produced by these highly impacted industries in the second quarter of 2019 (2019:Q2). The quarterly output of these industries is huge, around $\$ 1.37$ trillion, and they account for more than 25 percent of total U.S. GDP.

Let's suppose that if the COVID-19 pandemic had not occurred, then outputs and economic activities of these industries in the second quarter of 2020 (2020:Q2) would

\section{Labor Intensity and Output by Industry, 2019:Q2}

\begin{tabular}{lccc} 
& Labor intensity & $\begin{array}{c}\text { 2019:Q2 GDP } \\
\text { (billions) }\end{array}$ & $\begin{array}{c}\text { Maximum quarterly } \\
\text { wage loss (billions) }\end{array}$ \\
\hline Construction & 0.66 & 221.0 & 145.8 \\
\hline Retail trade (excluding food and beverage stores) & 0.54 & 251.0 & 136.8 \\
\hline Transportation and warehousing & 0.57 & 170.6 & 97.9 \\
\hline Administrative and waste management services & 0.73 & 167.5 & 121.5 \\
\hline Educational services & 0.77 & 65.1 & 218.4 \\
\hline Health care and social assistance (excluding hospitals) & 0.80 & 58.8 & 30.8 \\
\hline Entertainment and recreation & 0.52 & 164.2 & 102.7 \\
\hline Accommodation and food services & 0.63 & & 904.2 \\
\hline Total wage bills & & & \\
\hline $\begin{array}{l}\text { NOTE: Labor intensity is calculated using 2018 data. } \\
\text { SOURCE: Bureau of Economic Analysis (BEA) GDP by Industry and BEA National Income and Product Account (NIPA) Compensation of Employees } \\
\text { by Industry. }\end{array}$ & & \\
\hline
\end{tabular}




\section{ECONOMIC Synopses}

have been exactly the same as in 2019:Q2. If we employ the extreme assumption that these industries will produce zero output in 2020:Q2, we can estimate each industry's maximum lost wages for the current quarter by multiplying its labor intensity by its output. The maximum total wage loss for highly affected industries in 2020:Q2 reaches $\$ 904$ billion, or around $\$ 300$ billion each month. If we assume the output of each highly impacted industry falls to 50 percent of its 2019:Q2 value, the wage loss still reaches about $\$ 450$ billion for the quarter, therefore $\$ 150$ billion each month. The largest potential wage loss comes from the health care and social assistance industry, resulting from both its sizable share of total output as well as its high labor intensity.

In response to the economic shutdown, Congress recently passed the CARES Act. One component of CARES is that it expands the amount, eligibility, and payment period of unemployment insurance benefits. The cost of this component of CARES is estimated to be about $\$ 260$ billion, ${ }^{2}$ which certainly is a significant amount to at least partially cover the wages lost due to the COVID-19 pandemic. The actual coverage ratio heavily depends on the actual toll to the U.S. economy over the next few months.

\author{
Notes \\ 1 This industry list is consistent with the newest (April 2, 2020) initial jobless \\ claim report from the Department of Labor, in which many states report the \\ largest layoffs occurring in these industries listed above. \\ 2 Snell, K. "What's Inside the Senate's \$2 Trillion Coronavirus Aid Package." \\ NPR, March 26, 2020; https://www.npr.org/2020/03/26/821457551/whats-in- \\ side-the-senate-s-2-trillion-coronavirus-aid-package.
}

